\title{
Flowers and Value of Conservation in The Culture of Hindu Community in Bali
}

\author{
I Dewa Putu Darma*, Sutomo, Siti Fatimah Hanum, Rajif Iryadi, Ayyu Rahayu
}

\author{
Spatial Ecology Laboratory. Research Centre for Plant Conservation and Botanic Garden, \\ Indonesian Institute of Sciences (LIPI), Indonesia \\ *Corresponding Author: idpdarma@gmail.com
}

Submitted: 2020-11-09. Revised: 2020-12-08. Accepted: 2021-02-20

\begin{abstract}
Balinese Hindu community cannot be separated from plant in their life. The information on plant species and how to utilize them are easy to find but limited information about the potency of flowers in the Balinese Hindu community. Flowers have a meaning as sincerity, a symbol of Sang Hyang Widhi, the valour, and also have mythological values. This research aimed to determine the species of flowering plants that are often used for ceremonial and understand the meaning, the cultural conception related to conservation education. The study was carried out in four locations in Tabanan Regency (Baturiti, Penebel, Marga, and Tabanan). Data were collected using an interview with purposive sampling. Data analysis based on the value of Relative Frequency (FR) which is indicated plant most widely used. A total of 36 species of flowers are used in traditional Hindu religious ceremonies, of which 29 species are cultivated plants and 7 species are still wild. There are ten of plants which have high FR value, such as: Cananga odorata (FR 0.069), Impatiens balsamina (FR 0.069), Hydrangea macrophylla (FR 0.069), Plumeria acuminata (FR 0.069), Tagetes erecta (FR 0.069), Magnolia champaca (FR 0.069), Gomphrena globosa / bunga ratna (FR 0.047), Gardenia jasminoides / jempiring (FR 0.039), Nymphaea spp./ tunjung (FR 0.030), and Hibiscus rosa-sinensis L./ pucuk (FR 0.030). This research revealed the role of flower in Hindu ceremony and describe the strategic plant conservation due to culture of Balinese Hindu community. Finally, this research expected to documented local knowledge about flowers used as Hindu religious ceremonies, to provide an understanding of the meaning and conceptions of culture related to conservation education.
\end{abstract}

Key words: Cananga odorata; conservation; culture; education; Balinese Hindu Community

How to Cite: Darma, I. D. P., Sutomo, S., Hanum, S. F., Iryadi, R., \& Rahayu, A. (2021). Flowers and Value of Conservation in The Culture of Hindu Community in Bali. Biosaintifika: Journal of Biology \& Biology Education, 13(1), 34-40.

DOI: http://dx.doi.org/10.15294/biosaintifika.v13i1.27054

\section{INTRODUCTION}

Balinese Hindu community and their culture are inseparable from plant in their life. Flowers are an important means of carrying out Hindu religious ceremonies in Bali, which mean as an expression of gratitude to God Almighty (Peters \& Wardana, 2013). Flowers by the Hindu community in Bali in carrying out the ceremony are used to make canang, praying, making tirta, kumkuman water, and decorating sacred dances. The use of flowers in the ceremony's implementation is a cultural acculturation between traditional and modern cultures which shows life is dynamic. However, at present, local wisdom values have begun to fade, which impacts the loss of pride in offering flowers from own garden. Furthermore, specific information about the identity and meaning of the flowers used for the ceremony is very limited.

The development of an effective and practical community culture tends to adhere to an economic principle that forgets the process. In this matter, life cannot be alone as mandated in the Tri Hitakarana concept. This concept gives a mandate for harmony with God, man with man, and man with the environment. Arsana (2019) stated that the use of plants in ritual activities describes the complex relationship of knowledge, belief, and use (CorpusCosmos-Praxis). This complexity illustrates that the practice (praxis) of using plants in ritual activities is based on a strong belief system (cosmos) and a system of knowledge (corpus) about plants.

On the other hand, the understanding of the conception of cultural values related to plant conservation is still limited to the excitement of its implementation. Generally, people can make ceremonies and perform Yadnya ceremonies, but they do not understand what the ceremony is meant for (Putri et al., 2014). The criteria in choosing the type of flower for ceremonies is based on flower color, flower type, aroma, sacred (sukla) and local customs (loka dresta). But based on Lontar Yama Purana Tattwa, not all flower able to use in ceremonies, such as flower "camah" (not holy) like flower that are bitten or eaten by animals (Aryana, 2019). Furthermore, reasons from the religious side may also be related to the purpose of protecting nature which ecologically leads to human welfare (Sardiana, 2010). However, many publications focused on the type of used plant in Balinese culture (Putri et al., 2014; Ristanto et al., 2020; Sardiana \& Dinata, 2010), but the information about the potency of flower specifically in Balinese culture is limited, and refer to 
Adiputra (2011) that many young people do not know the types of ceremonial plants.

The knowledge they gain from the older generation is carried out orally by word of mouth. Furthermore, information delivery is also carried out by providing experience through direct practice during preparation, implementation, and postimplementation of religious ritual activities (Surata, Gata, \& Sudiana, 2015). Oral techniques and direct experience are superior in terms of practicality, but weak in terms of long-term availability of information. So, it is necessary to document the local knowledge about flowering plants used as Hindu religious ceremonies in Bali, both through print and electronic media. Thus, this knowledge can be accessed anytime and anywhere. The purpose of this study is to determine the species of flowering plants that are often used by the community for ceremonial activities and to provide an understanding of the meaning and conceptions of culture related to conservation education.

\section{METHODS}

\section{Study Area and Field Interview}

The research was conducted in four sub-districts in Tabanan Regency, namely Baturiti, Penebel, Marga, and Tabanan (figure 1). Each of these locations has 4 key informants so that there are 16 key samples. Interviews on the names of flowers, the use of flowers, and whether this plant cultivated or not were conducted by purposive sampling of community leaders, Banten craftsmen, canang sellers in the market and housewives. The information was recorded on a note.

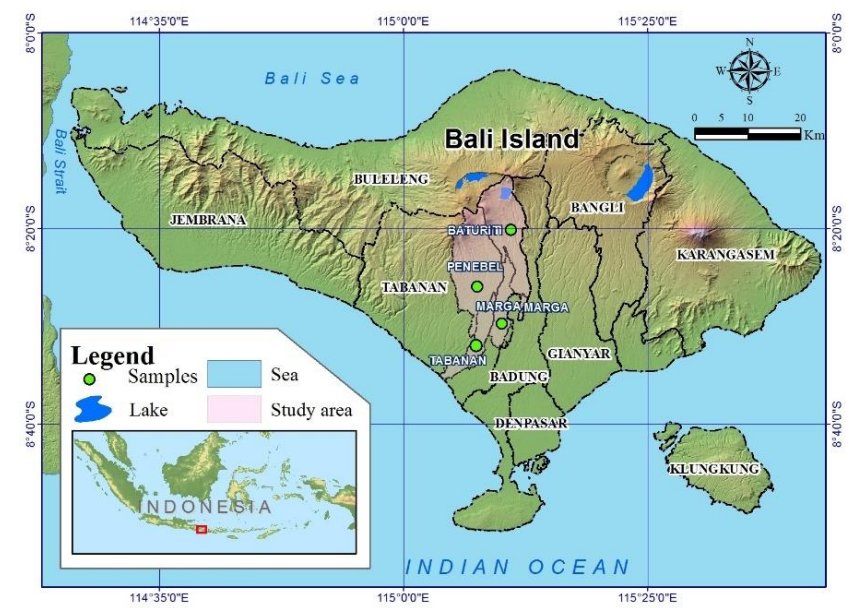

Figure 1. Study area survey located in Baturiti, Penebel, Marga, and Tabanan- Bali

\section{Data Analysis}

Data analysis was carried out using the Relative Frequency (FR) approach which is based on the appearance of information on plant types at the research location. Information species of flowers utilized as number data that has been divided by the total of informants (Kent, 2011; Mohammadi et al., 2020), with the formula as follow:

Information species of flowers utilized as number data that has been divided by the total of informants

$$
\begin{aligned}
& \mathrm{Fj} \\
& \text { FRj }=\text { - Fn }
\end{aligned}
$$

Information :

$\mathrm{FRj}=$ Relative frequency of the species of flowers utilized

$\mathrm{Fj}=$ Frequency of flowers used

$\mathrm{Fn}=$ Total number of informants

According to Kent (2011), high number of Relative Frequency indicates that the species is more widely distributed in the study area. This is assumed to be the same as the utilization so that the higher the Relative Frequency value of a plant, the more utilization of the plant.

\section{RESULTS AND DISCUSSION}

\section{Utilization of Flowers}

The results of the interview showed that as many as 36 species of flowers were used by the Hindu community in Bali, 29 of which were cultivated and 7 species were still wild (Table 1). The ten species of plants with the highest Relative Frequency (FR) were Cananga odoratalsandat (FR 0.069), Impatiens balsaminalkepacah (FR 0.069) (Fig.2.a), Hydrangea macrophylla/kembang seribu (FR 0.069), Plumeria acuminatal jepun (FR 0.069), Tagetes erectal gumitir (FR 0.069) (Fig.2.b) and Magnolia champacalcempaka (FR 0.069), Gomphrena globosalbunga ratna (FR 0.047), Gardenia jasminoides/jempiring (FR 0.039), Nymphaea spp./tunjung (FR 0.030) (Fig 2.d), and Hibiscus rosasinensis L./pucuk (FR 0.030). The ten species above have been cultivated by the community as cultivated plants in rice fields and moor or planted as ornamental plants in temples and home yards. The five species of plants commonly cultivated in the moor and paddy fields include Impatiens balsaminal kepacah, Hydrangea macrophyllalkembang seribu, Tagetes erectalgumitir, Gomphrena globosalbunga ratna and Nymphaea spp./tunjung. While the other 5 species that are planted as ornamental plants in the holy place (Pura) and the home yard are Cananga odorata/sandat, Plumeria acuminateljepun, Magnolia champacalcempaka, Gardenia jasminoides/ jempiring, and Hibiscus rosa-sinensis/pucuk. 


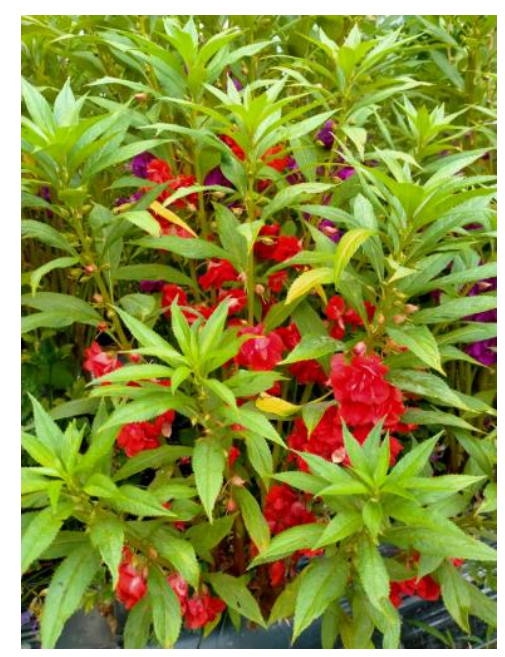

(a)

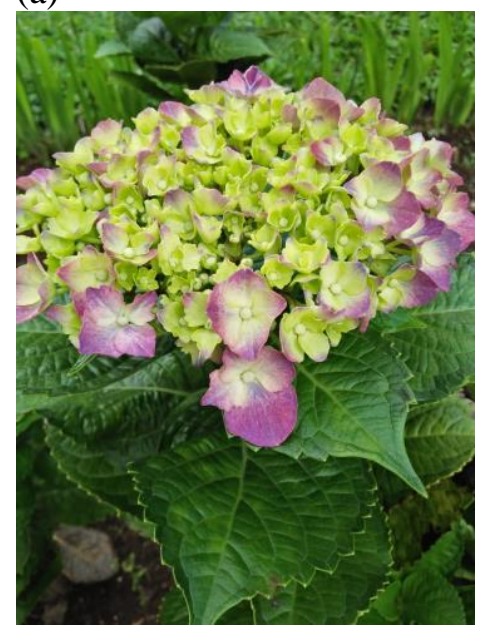

(c)

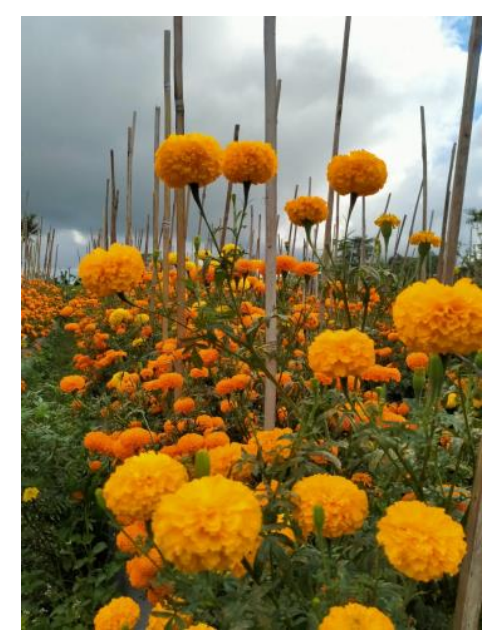

(b)

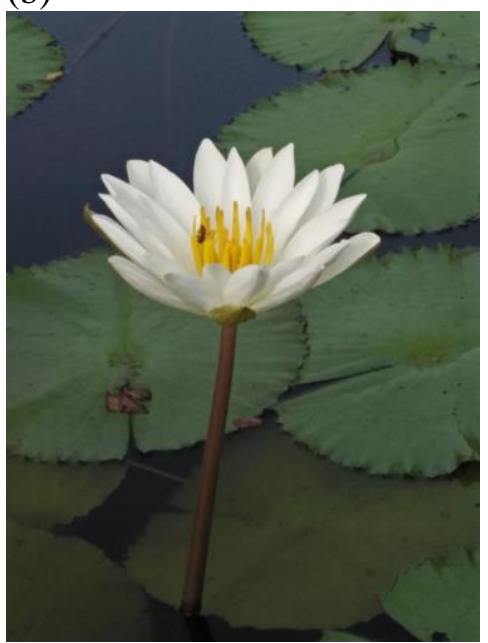

(d)

Figure 2. (a) Impatiens balsamina; (b) Tagetes erecta; (c) Hydrangea macrophylla; (d) Nymphaea sp.

Table 1. List of species of flowers used by the Hindu community in Bali

\begin{tabular}{|c|c|c|c|c|c|c|c|c|c|c|c|c|c|c|c|c|c|c|}
\hline \multirow[t]{2}{*}{ Species name/ Local name } & \multicolumn{4}{|c|}{$\begin{array}{l}\text { Baturiti } \\
\text { Dist }\end{array}$} & \multicolumn{4}{|c|}{$\begin{array}{l}\text { Penebel } \\
\text { Dist }\end{array}$} & \multicolumn{4}{|c|}{ Marga Dist } & \multicolumn{4}{|c|}{$\begin{array}{l}\text { Tabanan } \\
\text { Dist }\end{array}$} & \multirow[t]{2}{*}{ Sum } & \multirow[t]{2}{*}{ FRj } \\
\hline & $\mathrm{a}$ & $\mathrm{b}$ & $\mathrm{c}$ & $\mathrm{d}$ & $\mathrm{a}$ & $\mathrm{b}$ & $\mathrm{c}$ & $\mathrm{d}$ & $\mathrm{a}$ & $\mathrm{b}$ & $\mathrm{c}$ & $\mathrm{d}$ & $\mathrm{a}$ & $\mathrm{b}$ & $\mathrm{c}$ & $\mathrm{d}$ & & \\
\hline $\begin{array}{l}\text { Allamanda cathartica } \text { L./ bunga } \\
\text { coblong }\end{array}$ & 1 & 1 & & & & 1 & & 1 & 1 & 1 & & 1 & & 1 & & & 8 & 0.034 \\
\hline $\begin{array}{l}\text { Zinnia elegans Jacq./ kembang } \\
\text { kertas }\end{array}$ & & 1 & & & & 1 & & 1 & & & & 1 & & & & 1 & 5 & 0.021 \\
\hline $\begin{array}{l}\text { Thunbergia erecta (Benth.) T. } \\
\text { Anderson/ bunga pelung }\end{array}$ & & 1 & & & & 1 & & & & 1 & & & & 1 & & & 4 & 0.017 \\
\hline $\begin{array}{l}\text { Magnolia champaca (L.) Baill. ex } \\
\text { Pierre./ cempaka }\end{array}$ & 1 & 1 & 1 & 1 & 1 & 1 & 1 & 1 & 1 & 1 & 1 & 1 & 1 & 1 & 1 & 1 & 16 & 0.069 \\
\hline $\begin{array}{l}\text { Dioscorea hispida Dennst./ gadung } \\
*\end{array}$ & & & & & & & & 1 & & & & 1 & 1 & & & 1 & 4 & 0.017 \\
\hline Tagetes erecta L./ gumitir & 1 & 1 & 1 & 1 & 1 & 1 & 1 & 1 & 1 & 1 & 1 & 1 & 1 & 1 & 1 & 1 & 16 & 0.069 \\
\hline $\begin{array}{l}\text { Gardenia jasminoides J.Ellis./ } \\
\text { jempiring }\end{array}$ & 1 & & 1 & & 1 & 1 & & 1 & & 1 & & 1 & & 1 & & 1 & 9 & 0.039 \\
\hline Plumeria rubra L./ jepun & 1 & 1 & 1 & 1 & 1 & 1 & 1 & 1 & 1 & 1 & 1 & 1 & 1 & 1 & 1 & 1 & 16 & 0.069 \\
\hline $\begin{array}{l}\text { Anaphalis javanica Sch.Bip. } / \\
\text { sembung sari } *\end{array}$ & & & 1 & & & 1 & & & & & & & & 1 & & & 3 & 0.013 \\
\hline $\begin{array}{l}\text { Bougainvillea spectabilis Willd/ } \\
\text { kembang kertas. }\end{array}$ & & & 1 & 1 & & 1 & & 1 & & & 1 & & & & 1 & 1 & 7 & 0.030 \\
\hline Senna surattensis (Burm.f.) & & 1 & & 1 & 1 & & & 1 & & & & & 1 & & & 1 & 6 & 0.026 \\
\hline
\end{tabular}




\begin{tabular}{|c|c|c|c|c|c|c|c|c|c|c|c|c|c|c|c|c|}
\hline \multicolumn{17}{|l|}{$\begin{array}{l}\text { H.S.Irw } \\
\text { kuning }\end{array}$} \\
\hline $\begin{array}{l}\text { Clerodendrum thomsoniae Balf.f./ } \\
\text { kembang nyonya }\end{array}$ & & & 1 & 1 & & & 1 & & & 1 & & & & & 3 & 0.013 \\
\hline $\begin{array}{l}\text { Caesalpinia pulcherrima (L.) Sw./ } \\
\text { bunga kemerakan }\end{array}$ & & 1 & 1 & 1 & 1 & & 1 & & 1 & & & 1 & & & 6 & 0.026 \\
\hline $\begin{array}{l}\text { Murraya paniculata }(\text { L.) Jack/ } \\
\text { siulan* }\end{array}$ & & 1 & & & & & 1 & & & & 1 & & & & 3 & 0.013 \\
\hline Nerium oleander L./ kenyeri & & 1 & & 1 & & & 1 & & & & & & & & 3 & 0.013 \\
\hline Lilium longiflorum Thunb./ leli & & & 1 & 1 & & & 1 & & & & & & & & 2 & 0.009 \\
\hline $\begin{array}{l}\text { Dahlia pinnata Cav./ kembang } \\
\text { taram }\end{array}$ & & & 1 & 1 & & & & & & & & & & & 1 & 0.004 \\
\hline $\begin{array}{l}\text { Calotropis gigantea (L.) W.T.Aiton/ } \\
\text { manure* }^{*}\end{array}$ & & 1 & & & & 1 & & & 1 & & & 1 & & & 4 & 0.017 \\
\hline $\begin{array}{l}\text { Jasminum sambac (L.) Aiton/ } \\
\text { menuh }\end{array}$ & & 1 & & & 1 & & & & 1 & & 1 & & & & 4 & 0.017 \\
\hline Impatiens balsamina L./ kepacah & 1 & 11 & 11 & 1 & 1 & 1 & 11 & 11 & 1 & 1 & 1 & 1 & 1 & 1 & 16 & 0.069 \\
\hline $\begin{array}{l}\text { Hydrangea macrophylla (Thunb.) } \\
\text { Ser./ kembang seribu. }\end{array}$ & 1 & 11 & 1 & 1 & 1 & 1 & $\begin{array}{ll}1 & 1\end{array}$ & 11 & 1 & 1 & 1 & 1 & 1 & 1 & 16 & 0.069 \\
\hline $\begin{array}{l}\text { Cascabela thevetia (L.) Lippold/ } \\
\text { palet sedangan * }\end{array}$ & & 1 & & & 1 & & & & & & 1 & 1 & & & 4 & 0.017 \\
\hline Hibiscus rosa-sinensis L./ pucuk & 1 & 1 & 1 & 1 & 1 & & 1 & 1 & 1 & & 1 & & & & 7 & 0.030 \\
\hline Gomphrena globosa L./ bunga ratna & 1 & & & 1 & 1 & & & 11 & 1 & 1 & 1 & 1 & 1 & 1 & 11 & 0.047 \\
\hline $\begin{array}{l}\text { Elaeocarpus grandiflorus } \mathrm{Sm} . / \\
\text { rijase }\end{array}$ & & 1 & & & 1 & & & & & & 1 & & & & 3 & .013 \\
\hline Rosa pendulina L../ remawa & 1 & 1 & & 1 & 1 & & 11 & 1 & & & & & & & 6 & 0.026 \\
\hline $\begin{array}{l}\text { Rhododendron mucronatum (Blume) } \\
\text { G. Don/ rododendron }\end{array}$ & 1 & & 1 & L & & & 1 & & & & & & & & 3 & 0.013 \\
\hline $\begin{array}{l}\text { Cananga odorata (Lam.) Hook.f. \& } \\
\text { Thomson/ sandat }\end{array}$ & 1 & 11 & 1 & 1 & 1 & 1 & 11 & 11 & 1 & 1 & 1 & 1 & 1 & 1 & 16 & 0.069 \\
\hline $\begin{array}{l}\text { Chrysanthemum leucanthemum L./ } \\
\text { seruni }\end{array}$ & & 1 & & & 1 & & 1 & & & & & & & & 3 & 0.013 \\
\hline Aglaia odorata Lour./siulan. & 1 & & & & & & 1 & & & & & 1 & & & 3 & 0.013 \\
\hline Ixora coccinea L./soko & & 1 & 1 & l & 1 & & 1 & & & & & & & 1 & 5 & 0.021 \\
\hline Saraca indica L./ Sokaasti & & & & & 1 & & & & & & 1 & & & & 2 & 0.009 \\
\hline $\begin{array}{l}\text { Sambucus javanica Reinw. ex } \\
\text { Blume/ gegirang* }\end{array}$ & 1 & 1 & & & 1 & & 1 & 1 & & & 1 & & & & 5 & 0.021 \\
\hline $\begin{array}{l}\text { Clitoria ternatea } \text { L./teleng } * \\
\text { Medinilla sneciosa Blume/ nari }\end{array}$ & & 1 & & & 1 & & & & 1 & & & 1 & & & $\begin{array}{l}4 \\
2\end{array}$ & $\begin{array}{l}017 \\
009\end{array}$ \\
\hline $\begin{array}{l}\text { Medinilla speciosa Blun } \\
\text { Nymphaea sp./ tunjung }\end{array}$ & 1 & 1 & & 1 & 1 & & 1 & & & 1 & & 1 & 1 & & $\begin{array}{c}7 \\
233\end{array}$ & $\begin{array}{l}0.030 \\
1.000\end{array}$ \\
\hline
\end{tabular}

Information: $*=$ not yet cultivated, $\mathrm{a}=$ community leaders, $\mathrm{b}=$ Banten craftsmen, $\mathrm{c}=$ canang sellers, $\mathrm{d}=$ housewives, and $\mathrm{FRj}=$ Relative frequency of the species of flowers used.

The choice of flowers for the implementation of Hindu community ceremonies in Bali is based on flower color, flower species, aroma, sanctity, and local customs (loka dresta). Hindu Balinese has the Lontar as the directive on their culture and religion such as in Lontar Nawa Natya, Lontar Aji Janantaka, Lontar Yama Purana Tattwa, and Lontar Siwagama which are stated flowers that are good for ceremonies and taboo for religious ceremonies (Aryana, 2019). Flowers in the ceremony are used as a means of ceremony, namely for making canang, for praying, for making tirta, for making water for Kumkuman and for decoration for sacred dances. The following is an explanation of the use of flowers that be believed using these as symbolizes sincerity to God in ceremony.

\section{Flowers as a means of making canang}

Canang is a form of offering which is offered separately before God Almighty. The flowers chosen are those that are fresh, beautiful in color, fragrant and holy (sukla). The flowers used are Cananga odoratalsandat, Impatiens balsaminalkepacah, Hydrangea macrophyllalkembang seribu, Plumeria 
acuminataljepun, Tagetes erectalgumitir and Magnolia champacalcempaka, Gomphrena globosalratna, Gardenia jasminoides/jempiring, Nymphaea spp./tunjung, and Hibiscus rosa-sinensis L./pucuk. The placement of flowers must also follow the wind direction because each direction represents a different God according to his powers. The most types of flowers often used, among others, namely Magnolia alba which is white arranged from the east as a symbol Lord Shiva, Hibiscus rosa-sinensis in red is arranged in the south as a symbol of God Brahma, Magnolia champaca in yellow is arranged in the west direction as a symbol of Mahadeva, and the blue Impatiens balsamina (substituting for black) is arranged in the north as a symbol of God Vishnu (Ristanto et al., 2020)

\section{Flowers as a means of prayers}

Flowers are also used in the implementation of devotion, which is when the prayer is done by placing both hands over the head. The offerings are made five times (Panca Keramaning Sembah). The flowers used are Cananga odorata/sandat), Impatiens balsaminalkepacah, Hydrangea macrophyllal kembang seribu, Plumeria acuminataljepun, Tagetes erectalgumitir, Magnolia champacalcempaka, Gomphrena globosalratna flower, Gardenia jasminoides/jempiring, Nymphaea lotus L.Itunjung, and Hibiscus rosa-sinensis L./pucuk.

\section{Flowers as a means of drinking water}

Flowers in the Hindu customary community in Bali are also used to make kumkuman water (fragrant water) which means a means of cleansing, which is used in placenta cleaning, menek kelih ceremonies (puberty ceremony), and bathing of corpses. The flowers used are Cananga odorata/sandat, Plumeria acuminataljepun, Magnolia champacalcempaka and Gardenia jasminoides/jempiring.

\section{Flowers as a means of making tirta}

Tirta is always used in prayer by the Hindu community in Bali and it use is varied. Tirta in Balinese Hindu community ceremonies are varied, namely tirta pabérsihan, palukatan, panembak and pangentas. Tirta is also called wangsuh pada, cleaning water (bayu cokor) functions to cleanse contaminated and created thoughts. by priests with puja. The flowers used are Cananga odorata/sandat, Plumeria acuminata/jepun, Magnolia champacal cempaka, Gardenia jasminoides/jempiring, Nymphaea lotus L./tunjung.

\section{Flowers to decorate sacred dances}

Sacred dances called unen-unen are usually performed in large ceremonies such as nyatur, pemungkah, ngenteg linggih. These ceremonies are performed in kayangan tiga, dang kayangan, and sad kayangan. These sacred dances are the mask dance pajegan, barong, rangda, rejang, baris, pendet, sanghyang, wayang. Flowers to decorate this sacred dance use certain flowers. The barong and rangda dances use Hibiscus rosa-sinensis/pucuk and Plumeria acuminataljepun. The rejang dance uses Plumeria acuminataljepun, Tagetes erectalgemitir, Gomphrena globosalratna. Pendet dance uses Plumeria acuminataljepun. The use of these flowers is believed to have a sacred aura.

\section{Conservation Values in the Culture of Hindu Communities in Bali.}

Life that depends on nature should be closer to nature. It can be done by love nature well, get to know its characteristics, and how to manage it (Hilmanto, 2010). Furthermore, Widyatmoko \& Irawati (2017) stated that conservation can be defined as the maintenance and protection of something regularly to prevent damage and destruction by means of preservation or conservation. An efficient and effective conservation efforts able to encourage active people to participate in planting and maintaining plants used in ceremonies. The reasons for protecting nature are due to human interests, through protecting nature as part of itself and efforts that are ecological from a religious point of view (Steiner, 2012). Furthermore, (Doak et al., 2015) stated that modern conservation is an effort to preserve the earth's resources wisely. The management of biological resources able to optimally full fill the needs of human life today and in the future.

Culture is expected to be the basis for changes in social behavior related to conservation behavior. These changes can be fully based on awareness, sincerity, and seriousness in the social mobilization process (Aminrad et al., 2013). To ensure the success of conservation, local communities need to be involved to participate actively in order to get the benefits of conservation (Putri et al., 2014; I. Sardiana, 2010). Conceptions of strategic conservation in the culture of the Hindu community in Bali, namely;

\section{Concept of Utilization of Plants as a Means of Ceremony}

The implementation of Hindu community ceremonies in Bali cannot be separated from plants. Regarding conservation, Tri Hita Karana has become a strategic foundation in the conservation education of the Hindu community in Bali. Tri Hita Karana is the harmonious relationship between humans and God, humans and humans and humans with the 
environment. Ceremonies related to conservation include the Tumpek wariga ceremony, Wana kertih, Danu kertih, Nangluk merana, Tibe baya, Ngentegang woh papayonan and a series of ceremonies related to planting rice in rice fields (Darma, 2008). The relationship between plants and Bali ceremony, and vice versa, this gives a mandate to be used plant wisely and sustainably. Sustainable development does not only emphasize the system of economic income alone but also prioritizes the community socio-cultural system and environmental sustainability efforts for the future (Akbarini, 2016; Sujarwo et al., 2020).

\section{Sacred and Sacred Conception.}

The sacred or sacred understanding in Balinese society is usually associated with temples and upstream areas. While sacred or sacred conception is usually associated with spirits as tree dwellers. People usually call it tonyoan or banasan. Sacred and sacred conceptions will be able to guarantee protection of nature (Darma \& Sutomo, 2020).

\section{Traditional Conception of Penanggeh Plants.}

Penanggeh plants are a temporary substitute for trees that are felled, that is by piercing with plant branches. This is a sign or promise to replant. Furthermore, (Darma, 2008) stated that the tradition of cutting down trees is carried out by sticking plant branches in the former felled. This tradition is still carried out in some societies. Penanggeh tree is a promise to replant, plus the promise is a debt that must be returned.

\section{Concept of Arts in Conservation Education}

Bali has a variety of dances that can serve as information media for conservation education in Bali. According to Rondhi (2014), art can also be communicated in addition to aesthetics such as social and moral values. The strategic Balinese culture becomes an information media for plant conservation education. The art performances include masks, bondres, and shadow puppets. This performance is very communicative to transfer conservation education to an audience because the language is easy to understand by the community. Art is also applied in the arrangement of thematic gardens in the form of gardens in the Botanical Gardens located in Bali. Now in Bali there are 4 botanical gardens, namely the Jagatnatha Botanical Garden, Jembrana Regency which functions to collect Balinese medicinal and ceremonial plants from lowland habitats, the Gianyar Botanical Garden which functions to harvest ceremonial and medicinal plants for the middle area, the Belingkang Bangli Botanical Garden which function to conserve mountains ceremonial plants, while the Eka Karya Bali Botanical Garden managed by the central government (LIPI) serves to collect types of ceremonial plants with upland habitat. Eka Karya Bali Botanical Garden as a plant conservation organization in Bali since 2001 has been trusted by the Central Government, through development costs to actively participate in preserving, researching, and developing the types of ceremonial plants used by the Hindu community in Bali. Now the Eka Karya Bali Botanical Garden has a collection of 195 Balinese Hindu traditional ceremonial plants (Data from the Regitration Unit, August 2020) which are arranged in the form of a garden in Panca Yadnya Park covering an area of 5 ha. According to Sarna \& Sumardika (2004), the area which is strategic for conservation is a sacred place and yard that can be used as an ornamental plant.

In general, this study's results contributed to detailed information about certain flowers used in Balinese Hindu ceremonies. Balinese Hindus always pray to God every day using canang, which consists of flowers. This research also provides an understanding of the meaning and conceptions of culture related to conservation education. Hopefully, this article can provide new information for Balinese Hindus in particular and other communities about the potential of flower plants as a characteristic of ceremonies and the preservation of these plants in their gardens by planting plants that have the potential for traditional ceremonies.

\section{CONCLUSION}

A total of 36 types of flowers are used in Hindu community ceremonies in Bali. Ten species of flowers that are widely used are Cananga odoratal sandat, Impatiens balsaminalkepacah, Hydrangea macrophyllal kembang seribu, Plumeria acuminat jepun, Tagetes erectal gumitir, Magnolia champacal cempaka, Gomphrena globosal bunga ratna, Gardenia jasminoides/ jempiring, Nymphaea spp./tunjung, and Hibiscus rosa-sinensis L./pucuk. Conceptions of strategic conservation in the culture of the Hindu community in Bali, namely the conception of using flowers as a means of ceremony, giving a mandate for sustainable use, sacred conceptions is providing protection, penangah plant tradition is a promise to replant, and the concept of art in conservation education

\section{ACKNOWLEDGEMENT}

We thank the key respondents in Baturiti, Penebel, Marga, and Tabanan- Bali for contributing on this paper. 


\section{REFERENCES}

Adiputra, N. (2011). Tanaman Obat, Tanaman Upacara Dan Pelestarian Lingkungan. Bumi Lestari Journal of Environment, 11(2), 346-354.

Akbarini, D. (2016). Pohon pelawan (Tristaniopsis merguensis): Spesies kunci keberlanjutan Taman Keanekaragaman Hayati Namang-Bangka Tengah. AlKauniyah Jurnal Biologi, 9(1), 66-73.

Aminrad, Z., Zakariya, S., Hadi, A., \& Sakari, M. (2013). Relationship between awareness, knowledge and attitudes towards environmental education among secondary school students in Malaysia. World Applied Sciences Journal, 22(9), 1326-1333.

Arsana, I. N. (2019). Keragaman Tanaman Obat dalam Lontar "Taru Pramana" dan Pemanfaatannya untuk Pengobatan Tradisional Bali. Jurnal Kajian Bali, 09(01), 241-262.

Aryana, I. M. P. (2019). Nilai Ketuhanan Hindu dalam Sarana Upacara Bale Gading, 22(1), 1-17.

Darma, I. (2008). Upacara agama hindu di bali dalam perspektif pendidikan konservasi tumbuhan (suatu kajian pustaka). Udayana Mengabdi, 7(1), 7-16.

Darma, I. D., \& Sutomo. (2020). Konsepsi Nilai Budaya Dalam Pendidikan Konservasi Tumbuhan Masyarakat Di Sekitar Kawasan Hutan Bedugul Bali. Metamorfosa: Journal of Biological Sciences, $\quad 7(1), \quad 80-86 . \quad$ https://doi.org/: 10.24843/metamorfosa.2020.v07.i01.p11 h

Doak, D., Bakker, V., Goldstein, B., \& Hale, B. (2015). What is the future of conservation? In Protecting the wild (pp. 27-35). Washington, DC: Island Press.

Hilmanto, R. (2010). Etnoekologi. Bandar Lampung: Universitas Lampung.

I. B. Putu Sudarsana. (2010). Himpunan Tetandingan Upakara Yadnya. Denpasar: Yayasan Dharma Acarya.

Kent, M. (2011). Vegetation description and data analysis: a practical approach (2nd ed.). New York: John Wiley \& Sons.

Mohammadi, T., Pirani, A., \& Vaezi, J. (2020). A contribution to ethnobotany and review of phytochemistry and biological activities of the
Iranian local endemic species Sclerorhachis leptoclada Rech . f ., 45, 1-18.

Peters, J., \& Wardana, W. (2013). Tri Hita Karana. Jakarta: Kepustakaan Populer Gramedia.

Putri, R. I., Supriatna, J., \& Walujo, E. B. (2014). Ethnobotanical Study of Plant Resources in Serangan Island, Bali. Asian Journal of Conservation Biology, 3(2), 135-148.

Ristanto, R. H., Suryanda, A., Rismayati, A. I., Rimadana, A., \& Datau, R. (2020). Etnobotani: tumbuhan ritual keagamaan hindu-bali. JPBIO (Jurnal Pendidikan Biologi), 5(1), 96-105. https://doi.org/10.31932/jpbio.v5i1.642

Rondhi, M. (2014). Fungsi Seni bagi Kehidupan Manusia: Kajian Teoretik Imajinasi. Imajinasi : Jurnal Seni, 8(2), 115-128.

Sardiana, I. (2010). Unit pembibitan tanaman ritual (upakara). Majalah Aplikasi Ipteks Ngayah, 1(1), 13-21.

Sardiana, I. K., \& Dinata, I. K. K. (2010). Studi Pemanfaatan Tanaman Pada Kegiatan Ritual (Upakara)Oleh Umat Hindu Di Bali. Bumi Lestari Journal Of Environment, 10(1), 123-127.

Sarna, K., \& Sumardika, N. (2004). Tumbuhan Upacara Agama Hindu di Bali dalam Tantangan Zaman. In Prosiding Seminar Konservasi Tumbuhan Upacara Agama Hindu. (pp. 123-126). Tabanan: Kebun Raya 'Eka Karya' Bali.

Steiner, F. (2012). The living landscape: an ecological approach to landscape planning 2nd edition. Washington, DC: Island Press.

Sujarwo, W., Caneva, G., \& Zuccarello, V. (2020). Patterns of plant use in religious offerings in Bali (Indonesia). Acta Botanica Brasilica, 34(1), 4053.

Surata, I. ketut, Gata, I. W., \& Sudiana, I. M. (2015). Studi Etnobotanik Tanaman Upacara Hindu Bali sebagai Upaya Pelestarian Kearifan Lokal. Jurnal Kajian Bali (Journal of Bali Studies), 5(2), 265284.

Wiana, I. K. (2002). Makna Upacara Yadnya dalam Agama Hindu. Surabaya: ParamIta.

Widyatmoko, D., \& Irawati. (2017). Kamus Istilah Konservasi. Bogor: Pusat Konservasi Tumbuhan Kebun Kebun Raya Bogor LIPI. 